\title{
Clinical Characteristic and Outcome of Acute Lower Respiratory Tract Infection in Children with Congenital Heart Disease
}

\author{
Krystle Gabriela, ${ }^{1}$ Rahmat Budi Kuswiyanto, ${ }^{2}$ Fenny Dwiyatnaningrum ${ }^{3}$ \\ ${ }^{1}$ Faculty of Medicine Universitas Padjadjaran, ${ }^{2}$ Department of Child Health Faculty of Medicine, \\ Universitas Padjadjaran/Dr. Hasan Sadikin General Hospital Bandung, ${ }^{3}$ Department of Anatomy \\ and Cell Biology Faculty of Medicine Universitas Padjadjaran
}

\begin{abstract}
Background: Acute Lower Respiratory Tract Infection (ALRTI) is the leading cause of deaths in children under 5 years of age worldwide, and has high morbidity and mortality in children with Congenital Heart Disease (CHD). The objective of this study was to obtain the incidence, clinical characteristic, and outcome of ALRTI children with CHD.

Methods: A retrospective hospital-based study was conducted from January 2007-December 2011 to medical record of child patients with ALRTI and CHD in the Department of Child Health of Dr. Hasan Sadikin General Hospital, Bandung. The diagnosis of CHD was determined by echocardiography. The collected data was analyzed and presented in percentage shown in tables.

Results : From 3,897 children who had ALRTI, there were 149 children with CHD (3.8\%), with 11.4\% of whom founded with recurrent episodes. This happened often in girls than boys with quite similar ratio of 1.37: 1 .The majority of children (80\%) was under 1 year old of age, $72.5 \%$ with malnutrition, and $24.8 \%$ with severe malnutrition. Clinical symptoms mostly found were difficulty of breathing (98\%), fever (85.2\%), cough $(75.2 \%)$, and runny nose (63.1\%). The most common types of CHD were Patent Ductus Arteriosus (47.6\%), followed by Ventricular Septal Defect (47\%). Bronchopneumonia (86.6\%) was the common type of ALRTI. The length of stay was mostly less than 10 days (70.5\%). From all the children $43.7 \%$ had complications, and $6.7 \%$ died.

Conclusions: The ALRTI in children with CHD is not common and has good outcome. The majority for CHD lesions are Patent Ductus Arteriosus and Ventricular Septal Defect while for ALRTI is Bronchopneumonia. [AMJ.2015;2(3):403-8]
\end{abstract}

Keywords: Acute lower respiratory tract infection, congenital heart disease, outcome, malnutrition

\section{Introduction}

Acute Lower Respiratory Tract Infection (ALRTI) is the most common cause of death in children under five. Most cases of ALRTI in the world occurred in developing countries and Indonesia is in the sixth place. In 2010, the National Health Profile showed that ALRTI is one of the ten most frequent cases among hospitalized patients in Indonesia and has the highest mortality rate of 1,315 death..$^{1,2}$

Recurrent ALRTI often occurred in children with history of congenital heart diseases (CHD). The CHD is a disease that is most frequently found in children all over the world with a percentage of $28 \%$ of all types of congenital abnormalities, and the prevalence is about 9 per 1000 live-births in the last 15 years. ${ }^{3}$ Children with CHD are more vulnerable to recurrent respiratory tract infection. Considering that the children with CHD has an anatomy defect that causes hemodynamic disturbances of lung circulation, and it ultimately put them at higher risk to suffer from recurrent respiratory tract infection than those who has no history of CHD. ${ }^{4-6}$

The objective of this study was to obtain the incidence, clinical characteristic, and outcome of ALRTI children with CHD. The benefit of this study is to provide an early diagnosis for children with CHD in order to have a proper management plan.

\section{Methods}

A retrospective hospital based study was

Correspondence: Krystle Gabriela, Faculty of Medicine, Universitas Padjadjaran, Jalan Raya Bandung-Sumedang Km.21, Jatinangor, Sumedang, Indonesia, Phone: +62811185314 Email: krystle.gabriella@gmail.com 
conducted to ALRTI children with CHD at the Department of Child Health of Dr. Hasan Sadikin General Hospital; the study was held from January 2007-December 2011. The inclusion criteria were all ALRTI children with CHD who had undergone echocardiography (confirmed CHD). The exclusion criteria were children who had not undergone echocardiography
(CHD suspect) or incomplete medical record.

The medical records were evaluated and ALRTI children with confirmed CHD were selected. The data were collected, tabulated, and analyzed by using theStatistical Package for the Social Sciences (SPSS). The results were shown in proportion, mean, or median.

Table 1Characteristics of ALRTI Children with CHD

\begin{tabular}{|c|c|c|}
\hline Characteristics & $N=149$ & $\%$ \\
\hline \multicolumn{3}{|l|}{ Sex } \\
\hline Male & 63 & 57.7 \\
\hline Female & 86 & 42.3 \\
\hline \multicolumn{3}{|l|}{ Age Groups } \\
\hline 1 month & 8 & 5.4 \\
\hline 2 months - 1 year & 111 & 74.5 \\
\hline $2-5$ years & 18 & 12.1 \\
\hline $6-18$ years & 12 & 8.1 \\
\hline \multicolumn{3}{|l|}{ Nutritional Status } \\
\hline Good & 41 & 27.5 \\
\hline Mild malnutrition & 71 & 47.7 \\
\hline Severe malnutrition & 37 & 24.8 \\
\hline \multicolumn{3}{|l|}{ Clinical symptoms } \\
\hline Difficulty of breathing & 146 & 98 \\
\hline Fever & 127 & 85.2 \\
\hline Cough & 112 & 75.2 \\
\hline Runny nose & 94 & 63.1 \\
\hline Others & 37 & 24.3 \\
\hline \multicolumn{3}{|l|}{ Physical examination } \\
\hline Chest retraction & 133 & 89.3 \\
\hline Tachypnea & 130 & 87.2 \\
\hline Tachycardia & 112 & 75.2 \\
\hline Systolic murmur & 95 & 63.7 \\
\hline Crackles & 131 & 91.9 \\
\hline Cyanosis & 21 & 14.1 \\
\hline Others & 42 & 28.2 \\
\hline \multicolumn{3}{|l|}{ Lab } \\
\hline Anemia & 12 & 8.1 \\
\hline Leucocytosis & 36 & 24.2 \\
\hline \multicolumn{3}{|l|}{ Chest x-ray } \\
\hline Cardiomegaly & 92 & 61.7 \\
\hline Increase bronchovascular pattern & 113 & 75.8 \\
\hline Infiltrate & 120 & 80.5 \\
\hline
\end{tabular}


Krystle Gabriela, Rahmat Budi Kuswiyanto, Fenny Dwiyatnaningrum: Clinical Characteristic and Outcome of 405 Acute Lower Respiratory Tract Infection in Children with Congenital Heart Disease

Table 1Characteristics of ALRTI Children with CHD

\begin{tabular}{|c|c|c|}
\hline CHD & $\mathrm{N}=149$ & $\%$ \\
\hline \multicolumn{3}{|l|}{ Acyanotic } \\
\hline \multicolumn{3}{|l|}{ Left to right shunt } \\
\hline ASD & 27 & 18.1 \\
\hline VSD & 70 & 47 \\
\hline PDA & 71 & 47.6 \\
\hline \multicolumn{3}{|l|}{ Obstruction lesion } \\
\hline Aortic stenosis & 2 & 1.3 \\
\hline Pulmonary stenosis & 13 & 8.7 \\
\hline Interrupted aorta & 1 & 0.7 \\
\hline $\mathrm{CoA}$ & 7 & 4.7 \\
\hline \multicolumn{3}{|l|}{ Cyanotic } \\
\hline \multicolumn{3}{|c|}{ Decrease pulmonary blood flow } \\
\hline TOF & 7 & 4.7 \\
\hline Tricuspid atresia & 1 & 0.7 \\
\hline Pulmonary atresia & 5 & 3.4 \\
\hline \multicolumn{3}{|c|}{ Increase pulmonary blood flow } \\
\hline TGA & 4 & 2.7 \\
\hline DORV & 9 & 6 \\
\hline TAPVR & 3 & 2 \\
\hline Single ventricle & 1 & 0.7 \\
\hline Dextrocardia & 5 & 3.4 \\
\hline \multicolumn{3}{|l|}{ Valve anomalies } \\
\hline Mitral regurgitation & 20 & 13.4 \\
\hline Tricuspid regurgitation & 7 & 4.7 \\
\hline Aortic regurgitation & 1 & 0.7 \\
\hline Pulmonary regurgitation & 3 & 2 \\
\hline
\end{tabular}

\section{Results}

There were 3,897 children who suffered ALTRI and 149 of them were with history of CHD, who had already been confirmed by echocardiography and written on medical record, therefore, the incidence was $(149 / 3,897)=3.8 \%$. Out of 149 children, 17 (11.4\%) children had recurrent ALRTI.

The incidence of ALRTI in children with CHD were often found in girls than in boys with quite similar ratio of $1.37: 1$, and it occurred more frequently in children under 1 year of age $(80 \%)$. The median of age in this study was 6 months with the range of 1-156 month (one-month old-13 years old). Most of the children $(72.5 \%)$ had malnutrition of whom $47.7 \%$ with mild malnutrition and $27.5 \%$ with severe malnutrition. Malnutrition was associated with additional diagnosis of Failure to Thrive (12.8\%). Almost entire children who came to the hospital were complaining about breathing difficulty (98\%), cough (75.2\%), fever $(85.2 \%)$, and runny nose $(63.1 \%)$. Those are common signs and symptoms of ALTRI. Other symptoms were only complained by several children and probably associated with other common diseases that the children have e.g. diarrhea $(10.1 \%)$, seizure $(4.7 \%)$, vomit (4.7\%), breast feeding difficulty $(3.4 \%)$, decreased level of consciousness $(0.7 \%)$, and icteric $(0.7 \%)$. 
Table 3 Type of ALTRI

\begin{tabular}{lcc}
\hline \multicolumn{1}{c}{ ALTRI } & $\mathbf{N}=\mathbf{1 4 9}$ & $\mathbf{\%}$ \\
\hline Bronchopneumonia & 128 & 86.6 \\
Bronchiolitis & 16 & 10.7 \\
Lobar pneumonia & 4 & 2.7 \\
Laringotracheo bronchitis & 1 & 0.7 \\
\hline
\end{tabular}

According to statistical data tabulation for vital signs, the median for pulse rate was 134 times/minute (64-182), the median for respiratory rate was 56 times/minute (1882 ), and the mean for temperature was $37.60 \mathrm{C}$ +0.95 . Tachypnea $(87.2 \%)$ and tachycardia (75.2\%) were the most common signs found for vital abnormality. Most of the children $(893 \%)$ had chest retraction, but cyanosis wasfound only in a small number $(14.1 \%)$ of the children with cyanotic CHD. Abnormal heart sounds frequently heard on auscultation was systolic murmur (63.7\%), and the most common additional breathing sound was crackles $(91.9 \%)$. Other findings on physical examination were found in a small number of children such as continuous murmur (16.7\%), wheezing $(10.7 \%)$ and stridor $(0.7 \%)$.

Only few children were with leukocytosis $(24.2 \%)$, so most of the children had a normal number of white blood cells. Only a small number of children had anemia $(8.1 \%)$. As shown in the chest x-ray, infiltrate $(80.5 \%)$ and increase of Broncho vascular pattern $(75.8 \%)$ were the common findings in children with ALRTI. Enlargement of the heart (cardiomegaly) was found in most of the patients $(92 \%)$ related to CHD.
The CHD was commonly found in children hospitalized with ALRTI, and the most common defect were PDA (47.6\%) and VSD (47\%). Both diseases defected with the presence of shunt from left to right. The most common type of ALTRI was bronchopneumonia (86.6\%).

Based on statistical data tabulation for length of stay, the median was 8 days (1-58). In this study, most of the children hospitalized were in range of 1-10 days (70.5\%). As much as $83.9 \%$ of the children was discharged with good condition. Some of the children had complications, such as heart failure $(22.8 \%)$ and respiratory failure (16.1\%), however, only few children died (6.75\%).

\section{Discussion}

The incidence of ALRTI in children with CHD is lower than a previous study by Owayed et al. ${ }^{7}$, which reported the incidence of CHD children hospitalized because of recurrent pneumonia was $9 \%$. The low result of this study is probable since not all of the children have undergone the echocardiography, or as this is a single center study. In Indonesia, there are still many children who have no health service coverage

Table 3 Type of ALTRI

\begin{tabular}{lcc}
\hline \multicolumn{1}{c}{ Outcome } & $\mathbf{N}=\mathbf{1 4 9}$ & $\mathbf{\%}$ \\
\hline Length of stay & & \\
1-10 days & 105 & 70.5 \\
11-20 days & 33 & 22.1 \\
$21-30$ days & 10 & 6.7 \\
$>30$ days & 1 & 0.7 \\
Outcome & & \\
Good & 125 & 83.9 \\
Death & 10 & 6.7 \\
Complication & & \\
$\quad$ Heart failure & 34 & 22.8 \\
$\quad$ Respiratory failure & 24 & 16.1 \\
\hline
\end{tabular}


Krystle Gabriela, Rahmat Budi Kuswiyanto, Fenny Dwiyatnaningrum: Clinical Characteristic and Outcome of 407 Acute Lower Respiratory Tract Infection in Children with Congenital Heart Disease

because of the low socio economic status and the fact that the social health insurance does not cover the echocardiography cost yet.

Recurrent ALRTI in children with CHD was more frequently in baby under 1 year of age. This fact is due to the low capacity of children immune system and the small size of respiratory tract. The lesion commonly found was left to right lesion, which caused low vascular resistance that would increase the vulnerability of infection in child with CHD. ${ }^{5}$ Nutritional disturbances will affect immune system, therefore it will increase the risk of infection and slowing down the healing process. Study by Caulfield et al. ${ }^{8}$ in 2004 showed that $52.3 \%$ of death due to ALRTI was associated with malnutritions. ${ }^{8}$ In the study generated by Nataprawira et al. ${ }^{6}$, showed that malnutrition was one of risk factors for morbidity and mortality of severe pneumonia on children under age of 5 . Malnutrition associated with Failure to Thrive (FTT). In this study, FTT was found in $12.8 \%$ children. Shah et al. ${ }^{9}$ reported FTT was found in $11.9 \%$ children with CHD. The FTT is a major symptom of CHD because of low energy expenditure, inadequate food intake, and malabsorption or feeding difficulties.

According to WHO classifications for pneumonia; if difficulty of breathing occurred, then a child should be diagnosed with severe pneumonia and required hospitalization. Tachypnea was symptoms of respiratory disturbance which has high both sensitivity and specificity in diagnosing pneumonia. Crackles (wet ronchi) was specific additional breath sound found in children with pneumonia. ${ }^{10,11}$

The ALRTI, caused by neither virus nor bacteria, was often preceded by upper respiratory tract infection for several days. ${ }^{12}$ Children with CHD are at risk for increased morbidity from viral lower respiratory tract infections because of anatomical cardiac lesions than can worsen an already compromised respiratory status. ${ }^{13}$ However, it is difficult to differentiate between bacterial and viral infection only by clinical symptoms and physical examination. Therefore, many broad spectrum antibiotics are empirically used in management of ALRTI. ${ }^{10}$ Based on our study, the most frequent initial antibiotic given were ampicillin (35.6\%) and combination between ampicillin and gentamicin (14.1\%). In our institution, ampicillin is the initial antibiotic given, but in severe clinical condition, initial antibiotic given is combination of ampicillin and gentamicin or ampicillin and chloramphenicol. ${ }^{14}$
Chest X-ray image inpatient with ALRTI can be in form of mild infiltrate in one lung until extensive consolidation in both lungs. The presence of infiltrate and the increase of Broncho vascular pattern are specific radiologic findings for bronchopneumonia. ${ }^{10}$ If cardiomegaly was present, then a patient is more likely to be diagnosed as heart failure. This phenomenon happened because of wide shunt from right side to left side of the heart. ${ }^{15}$ If heart failure exist, the child should be given anti heart failure drugs such as diuretic (furosemide), vasodilator (captopril) and digitalis (digoxin). ${ }^{15}$ Based on the study, the combination of those three drugs were the most frequent anti heart failure drugs given $(11.4 \%)$.

In the study generated by Wilar and Wantania $^{5}$, acyanotic CHD (61.7\%) has greater number of patients than cyanotic CHD (38.3\%), and ALTRI occurs more frequent in children with CHD than in normal children, especially children with bronchopneumonia $(86.6 \%)$. Cahyono and Rachman $^{4}$ reported that $50 \%$ of death case in children with CHD was underlined by pneumonia.

The child who was hospitalized only for 1 day was due to severe complication that causes death. In ALRTI without complications, length of stay within antibiotic administration was 7-10 days less or more. ${ }^{10}$ The most common indicator for the use of ventilator was acute respiratory failure which was frequently caused by bronchopneumonia $(31.1 \%)$ and the majority was under the age of 1 year. ${ }^{16} \mathrm{~A}$ child who died is suspected due to improper management or severe complications. Respiratory and cardiac failure were two leading cause of death and death rate was significantly high in malnourished children. ${ }^{4}$

Limitations of this study were unavailable medical record or incomplete medical record data. Since this study was a hospital-based type, the data were obtained from a single health center only, therefore the result is not quite representative, and not all the patients underwent echocardiography.

As a suggestion, a further study in children with CHD who have been hospitalized due to ALRTI that involve several health centers is necessary. Clear registration and administration of medical records should be enforced thus, all data in medical records can be completed. Furthermore, improving the health services system in order to extend the coverage of health services especially for those with financial limitation is needed. Also it is important to increase suspiciousness 
in the present of CHD and encourage echocardiography test for children with recurrent ALRTI and failure of thrive.

The incidence of ALRTI children with CHD is $3.8 \%$, in which $11.4 \%$ children had recurrent ALRTI. Nutritional status for severe malnutrition, moderate malnutrition, and good nutritional status were $47.7 \%, 24.8 \%$, and $27.5 \%$, respectively. The most frequent clinical symptoms were difficulty of breathing (98\%), fever (85.2\%), cough (75.2\%), and runny nose (63.1\%). The most common type of CHD was PDA (47.6\%) and VSD (47\%), whilst type of ALRTI was bronchopneumonia (86.6\%). The length of stay of patients was less than 10 days $(70.5 \%)$ and the outcome was mostly good (83.9\%) Even though almost half of the patients present were with complications $(43.7 \%)$, but only a small number resulted in death $(6.7 \%)$.

\section{References}

1. Wardlaw T, Johansson EW, Hodge M. Pneumonia: the forgotten killer of children. UNICEF. 2006 [Cited 2012 April 15]. Available from: http://www.unicef. org.

2. Kementrian Kesehatan RI. Profil kesehatan Indonesia. Kementrian Kesehatan RI. 2010 [Cited 2012 April 15]. Available from: http://www.depkes.go.id

3. van der Linde D, Konings EEM, Slager MA, Witsenburg M, Helbing WA, Takkenberg JJM, et al. Birth prevalence of congenital heart disease worldwide. J Am Coll Cardiol. 2011;58(21):2241-7.

4. Cahyono A, Rachman MA. The cause of mortality among congenital heart disease patients in pediatric ward, Soetomo General Hospital (2004-2006). J Kardiol Ind. 2007;28(4):279-84.

5. Wilar R, Wantania JM. Beberapa faktor yang berhubungan dengan infeksi saluran pernapasan akut pada anak dengan penyakit jantung bawaan. Sari Pediatri. 2006;8(10):154-8.

6. Nataprawira HM, Alwi EH, Adriani N. Faktor risiko morbiditas dan mortalitas pneumonia berat pada anak usia balita. Maj Kedokt Indon. 2010;60(10):443-7.
7. Owayed AF, Campbell DM, Wang EEL. Underlying causes of recurrent pneumonia in children. Arch Pediatr Adolesc Med. 2000;154(2):191-4.

8. Caulfield LE, Onis Md, Blossner M, Black RE. Undernutrition as an underlying cause of childs death associated with diarrhea, pneumonia, malaria and measles. Am J Clin Nutr. 2004;80(1):193-8.

9. Shah G, Singh M, Pandey T, Kalakheti $\mathrm{B}$, Bhandari G. Incidence of congenital heart disease in tertiary care hospital. Kathmandu Univ Med J. 2008;6(21):33-6.

10. Said M. Infeksi respiratori akut: Pneumonia. In: Rahajoe NN, Supriyatno B, Setyanto DB, editors. Buku ajar respirologi anak. 1st ed. Jakarta: Ikatan Dokter Anak Indonesia. 2010. p. 350-64.

11. Palafox M, Guiscafre H, Reyes H, Munoz O, Martinez H. Diagnostic value of tachypnoe in pneumonia defined radiologically. Arch Dis Child. 2000;82(1):41-5.

12. Sectish TC, Prober CG. Pneumonia. In: Kliegman RM, Behrman RE, Jensen HB, Stanton BF, editors. Nelson Textbook of Pediatrics. 18th ed. Philadelphia: Saunders; 2007. p. 1795-800.

13. Geskey JM, Cyran SE. Managing the morbidity associated with respiratory viral infection in children with congenital heart disease. Int J Ped. 2012;2012:646780.

14. Kartasasmita CB, Suardi AU, Nataprawira HM, Sudarwati S, Wulandari DA. Respirologi. In: Garna H, Nataprawira HM, editors. Pedoman diagnosis dan terapi ilmu kesehatan anak. Bandung: Departemen Ilmu Kesehatan Anak Fakultas Kedokteran Universitas Padjadjaran; 2012. p. 781-878.

15. Firman A, Rahayuningsih SE, Kuswiyanto RB. Kardiologi. In: Garna H, Nataprawira HM, editors. Pedoman diagnosis dan terapi ilmu kesehatan anak. 4th ed. Bandung: Departemen Ilmu Kesehatan Anak Fakultas Kedokteran Universitas Padjadjaran; 2012. p. 477-559.

16. Hakim DL, Ismawaty N. Karakteristik penderita yang mendapat tindakan ventilasi mekanik yang dirawat di ruang perawatan intensif anak Rumah Sakit Hasan Sadikin Bandung. MKB. 2007;39(2):75-9. 